\title{
報文
}

\section{魚油とコーン油の配合比率を異にした油脂を 投与したラットの脂肪酸組成}

\author{
滝 田 聖 親, 早川享志, 中村力ホル \\ 福富麻子, 印南敏 \\ 東京農業大学農学部栄養学科
}

\author{
Effects of Different Combinations of Fish Oil and Corn Oil \\ in the Diets on Lipid Metabolism in Rats \\ Toshichika TAKITA, Takashi HAYAKAWA, Kaoru NAKAMURA, \\ Asako FUKUTOMI and Satoshi INNAMI \\ Department of Nutrition, Faculty of Agriculture, Tokyo University \\ of Agriculture, Setagaya-ku, Tokyo 156
}

\begin{abstract}
Nippon Eiyō Shokuryō Gakkaishi (J. Jpn. Soc. Nutr. Food Sci.) 42, 227 234 (1989)
The lipid contents of plasma and liver and the fatty acid compositions of plasma, platelets, liver, testes and epididymal adipose tissues were measured in rats fed diets containing different combinations of fish oil and corn oil. While no significant differences were observed in plasma triglyceride levels among the experimental groups, plasma cholesterol level decreased as the proportion of dietary fish oil increased. However the levels of cholesterol and phospholipid in the liver increased with an increasing proportion of dietary fish oil. In plasma, liver and testes, the percentages of $\mathrm{C}_{20: 5}(n-3)$ and $\mathrm{C}_{22: 6}(n-3)$ were reduced as the proportion of dietary fish oil decreased and the percentages of $\mathrm{C}_{18: 2}(n-6)$ and $\mathrm{C}_{20: 4}$ $(n-6)$ increased as the proportion of dietary corn oil increased. In platelets, the percentage of $\mathrm{C}_{18: 2}$ was high and that of $\mathrm{C}_{20: 4}$ was low in the groups receiving more than $50 \%$ fish oil, while opposite results were seen in the groups receiving more than $75 \%$ corn oil. The $C_{20: 4} / C_{18: 2}$ ratios varied in each tissue and also among the dietary groups receiving different combinations of fish oil and corn oil.
\end{abstract}

(Received June 17, 1988)

従来より動脈硬化性疾患は飽和脂肪酸の摂取量が多 く, 多価不飽和脂肪酸 (PUFA) の摂取量の少ない場合 に発症しやすいことがすでに知られている。PUFA とし ては $n-6$ 系 PUFA と $n-3$ 系 PUFA とがあるが，最 近まで, 動脈硬化性疾患を予防するらえで重要視されて きたものは，植物油に多く含まれる， $n-6$ 系 PUFA の リノール酸であった。

ところが, Dyerberg ら122)のエスキモー人に関する疫 学調查以来, 魚油に含まれる $n-3$ 系の PUFA であるエ イコサペンタェン酸（EPA）とドコサヘキサエン酸 (DHA) の生理作用が注目されるようになった334)。

厂156 東京都世田谷区桜丘 1-1-1
EPA D DHA は血清総コレステロール (TC) および トリグリセライド(TG) の低下, HDL-コレステロール （HDL-Chol）の上昇といった血清脂質改善作用を有する ことが明らかにされている576)。さらに，EPA はトロン ボキサン $\left(\mathrm{TXA}_{2}\right)$ やプロスタグランジン $\mathrm{H}_{2}\left(\mathrm{PGH}_{2}\right)$ の 合成を低下させ778)，あるいは $\mathrm{TXA}_{2} や \mathrm{PGH}_{2}$ による血 小板凝集反応を阻害( ${ }^{9110)}$ ，血小板凝集による血栓生成 を防止しらると考兄られている。このような観点から PUFA のなかでも $n-3$ 系 PUFA の重要性が最近見直さ れてきている。

しかし, $n-3$ 系 PUFA の必要量や, 適切な $n-3 \mathrm{P} / n$ 6P 比などに関する基脴的研究は少ないが，Mouri ら ${ }^{111}$ は, 試験油脂中の魚油の配合割合が高まるのに対応して 
血清脂質が有意に低下することを認め, Lee ら ${ }^{12)} は$ ，種 々の脂質パラメータが食事脂質の $\mathrm{P} / \mathrm{S}$ 比扰よび $n-3 \mathrm{P} /$ $n$-6P 比により微妙に調節されており, 両比に最適比率 が存在するだろうと示唆している。そこで, 今回はこれ らの問題を解明する基礎的研究としてラットを用い, 魚 油とコーン油の配合割合を段階的に変えた場合の脂質代 謝変動について検討したので報告する。

\section{実 験 方 法}

\section{1. 実験動物および飼育条件}

4 週龄の SD 采の雄ラットを 1 週間, 基本飼料で子備 飼育後， 1 群 6 匹とし，ステンレス製ケージに 1 匹ずつ 入れた。すべての飼育は 12 時間明暗交替（明 $08: 00$ 20 : 00) の恒温（温度 $23 \pm 1^{\circ} \mathrm{C}$, 湿度 $50 \pm 5 \%$ ) の飼育 室で行い, 飼料および水は自由摂取とし, 飼育期間は 3 週間とした。

飼育終了後, 午前 6 時に慨を抜き取り, 午後 1 時にネ ンブタール麻酔下で, 心蔵より採血し, 常法により血小 板を分離した。頸椎脱目による屠殺後, 肝臓, 鋅丸およ び副睪丸周辺脂肪組織を摘出し分析に供した。

\section{2. 飼料組成}

試験油脂を除く飼料組成は，カゼイン $20.0 \%$ ，DL-メ チオニン $0.3 \%$ ，コーンスターチ $60.0 \%$ ，七ルロース粉 末 $5.0 \%$ ，ミネラル混合 (AIN-76) 3.5\%，ビタミン混 合 (AIN-76) $1.0 \%$ および重酒石酸コリン $0.2 \%$ とし た。試験油脂は魚油 (sardine-body oil) とコーン油の配 合割合の異なる 5 種の油脂を用い，それぞれ $10 \%$ レべ ル含むように調製した。魚油とコーン油の配合比率は I 群が $100: 0$, II 群が $75: 25$, III群が $50: 50$, IV群が $25: 75$ およびV群が $0: 100$ とした。なお，魚油の脂肪 酸組成は, $\mathrm{C}_{14: 0} 5.6 \%, \mathrm{C}_{16: 0} 15.2 \%, \mathrm{C}_{16: 1} 7.5 \%, \mathrm{C}_{18: 0}$ $2.5 \%, \mathrm{C}_{18: 1} 17.3 \%, \mathrm{C}_{18: 2}(n-6) 1.3 \%, \mathrm{C}_{18: 4}(n-3)$ $2.4 \%, \mathrm{C}_{20: 1} 8.3 \%, \mathrm{C}_{20: 5}(n-3) 13.2 \%, \mathrm{C}_{22: 1} 6.3 \%$,
$\mathrm{C}_{22: 5}(n-3) 1.7 \%$ および $\mathrm{C}_{22: 6}(n-3) 10.7 \%$ である。 コーン油の脂肪酸組成は， $\mathrm{C}_{16: 0} 10.4 \% ， \mathrm{C}_{18: 0} 1.7 \%$, $\mathrm{C}_{18: 1} 25.4 \%, \mathrm{C}_{18: 2}(n-6) 60.8 \%$ 扩よび $\mathrm{C}_{18: 3}(n-3)$ $0.7 \%$ である。また, 各群の $n-3 \mathrm{P} / n-6 \mathrm{P}$ 比と $\mathrm{P} / \mathrm{S}$ 比 は，それぞれI群が 14.8 と 1.3 , I群が 1.4 と 1.9 , III群が 0.5 と2.5, IV群が 0.2 と 3.5 およびV群が 0.0 と 4.9 であった。

\section{3. 分 析 法}

肝臓と血獎中の $\mathrm{TC}$, リン脂質 (PL), TG および血 獎中の HDL-Chol は和光純薬製のキットを用いて測定 した。

脂肪酸組成はクロロホルム：メタノール混液で抽出 後, 三フッ化ホウ素メタノール法でメチル化後, 島津 GC-7A 型ガスクロマトグラフを用いて測定しだ。分析 は Silar-5CP ガラスキャピラリーカラム $(40 \mathrm{~m})$ を用 い, カラム温度 $200^{\circ} \mathrm{C}$, 注入口温度 $250^{\circ} \mathrm{C}$, キャリアガ スにはへリウムガスを用いて行った。

ピークの同定は標品との保持時間の比較, 同族体の炭 素数と保持時間の関係を利用して行った。

実験結果は，平均と標準誤差で表した。各群の有意差 の検定を分散分析法拉よび Student's $t$-test を用いて行 った。

\section{結果}

\section{1. 血漿と肝䁍脂質の変動}

1) 血獎脂質 飼料脂質の魚油とコーン油の配合比率 を変えた場合の血漿脂質の変動は Table 1 に示した。

血漿 TC と HDL-Chol はコーン油の配合比率が増加 するにつれて上昇することが認められた。TCの低下作 用は $n-3$ 系 PUFA が, HDL-Chol の上昇作用は $n-6$ 系 PUFA がそれぞれ強い傾向を示した。

TG と PL は各群間に有意差が認められなかった。

2) 肝臟脂質 魚油とコーン油の配合比率の異なる飼

Table 1. Effects of different combinations of fish oil and corn oil in diets on plasma lipid concentrations $(\mathrm{mg} / \mathrm{dl})$.

\begin{tabular}{lccccc}
\hline \hline \multirow{2}{*}{ Lipids } & \multicolumn{5}{c}{ Group } \\
\cline { 2 - 6 } & I & II & III & IV & V \\
\hline TC & $52.7 \pm 2.5^{\mathrm{a}}$ & $58.6 \pm 3.9^{\mathrm{a}}$ & $56.0 \pm 2.7^{\mathrm{a}}$ & $61.5 \pm 3.2^{\mathrm{ab}}$ & $67.8 \pm 2.3^{\mathrm{b}}$ \\
HDL-Chol & $44.6 \pm 1.3^{\mathrm{a}}$ & $48.3 \pm 3.5^{\mathrm{b}}$ & $46.2 \pm 1.7^{\mathrm{a}}$ & $51.3 \pm 1.1^{\mathrm{ab}}$ & $61.0 \pm 1.8^{\mathrm{bc}}$ \\
TG & $85.0 \pm 6.5$ & $104.5 \pm 8.2$ & $106.6 \pm 6.2$ & $115.8 \pm 10.0$ & $99.8 \pm 9.2$ \\
PL & $86.5 \pm 3.7$ & $96.0 \pm 4.6$ & $93.8 \pm 3.5$ & $101.8 \pm 6.8$ & $105.3 \pm 4.2$ \\
\hline \hline
\end{tabular}

The percentages of dietary fish oil and corn oil for the groups: (I ) $10: 0$, (II) $7.5: 2.5$, (III) $5.0: 5.0$, (IV) $2.5: 7.5$, (V) $0: 10$. TC, total cholesterol; HDL-Chol, HDL-cholesterol; TG, triglyceride; PL, phospholipid.

Values are means \pm SE. $(n=6)$. Values in a horizontal line not sharing a common superscript letter are significantly different at $p<0.05$. 
Table 2. Effects of different combinations of fish oil and corn oil in diets on liver lipid concentrations ( $\mathrm{mg} / \mathrm{g}$ liver).

\begin{tabular}{lccccc}
\hline \hline \multirow{2}{*}{ Lipids } & \multicolumn{5}{c}{ Group } \\
\cline { 2 - 6 } & I & II & III & IV & V \\
\hline TC & $2.3 \pm 0.1^{\mathrm{a}}$ & $2.4 \pm 0.1^{\mathrm{a}}$ & $2.0 \pm 0.1^{\mathrm{b}}$ & $2.0 \pm 0.1^{\mathrm{b}}$ & $1.7 \pm 0.1^{\mathrm{b}}$ \\
TG & $27.4 \pm 2.1$ & $35.1 \pm 5.1$ & $26.8 \pm 1.5$ & $29.5 \pm 1.5$ & $31.0 \pm 2.0$ \\
PL & $31.0 \pm 1.2^{\mathrm{a}}$ & $27.9 \pm 0.6^{\mathrm{ab}}$ & $25.5 \pm 1.0^{\mathrm{b}}$ & $27.4 \pm 0.7^{\mathrm{ab}}$ & $25.7 \pm 0.9^{\mathrm{b}}$ \\
\hline \hline
\end{tabular}

The percentages of dietary fish oil and corn oil for the groups : (I ) $10: 0$, (II) $7.5: 2.5$, (III) $5.0: 5.0$, (IV) $2.5: 7.5$, (V) $0: 10$. TC, TG, PL : See footnote in Table 1.

Values are means \pm SE. $(n=6)$. Values in a horizontal line not sharing a common superscript letter are significantly different at $p<0.05$.

Table 3. Effects of different combinations of fish oil and corn oil in diets on fatty acid composition of plasma lipids $(\%)$.

\begin{tabular}{|c|c|c|c|c|c|}
\hline \multirow{2}{*}{ Fatty acids } & \multicolumn{5}{|c|}{ Group } \\
\hline & $\mathrm{I}$ & II & III & IV & $\mathrm{V}$ \\
\hline $\mathrm{C}_{14: 0}$ & $1.2 \pm 0.1^{\mathrm{a}}$ & $1.0 \pm 0.1^{a c}$ & $0.9 \pm 0.1^{\mathrm{bce}}$ & $1.0 \pm 0.2^{\mathrm{ace}}$ & $0.6 \pm 0.0^{\mathrm{bde}}$ \\
\hline $\mathrm{C}_{16: 0}$ & $23.6 \pm 0.4^{\mathrm{a}}$ & $23.0 \pm 0.8^{\mathrm{ac}}$ & $21.0 \pm 0.7^{\text {bce }}$ & $21.7 \pm 1.0^{\text {ace }}$ & $19.6 \pm 0.3^{\mathrm{bd} \theta}$ \\
\hline $\mathrm{C}_{16: 1}$ & $4.0 \pm 0.2^{\mathrm{a}}$ & $3.6 \pm 0.2^{\mathrm{a}}$ & $2.3 \pm 0.2^{\mathrm{b}}$ & $2.6 \pm 0.3^{b}$ & $1.6 \pm 0.2^{\mathrm{c}}$ \\
\hline $\mathrm{C}_{18: 0}$ & $8.6 \pm 0.4$ & $7.8 \pm 0.3$ & $7.8 \pm 0.4$ & $8.3 \pm 0.6$ & $9.1 \pm 0.3$ \\
\hline $\mathrm{C}_{18: 1}$ & $16.4 \pm 0.6^{\mathrm{a}}$ & $15.6 \pm 1.1^{\mathrm{a}}$ & $15.2 \pm 0.8^{\mathrm{a}}$ & $14.9 \pm 1.3^{\mathrm{ab}}$ & $12.1 \pm 0.9^{b}$ \\
\hline $\mathrm{C}_{18: 2}(n-6)$ & $4.9 \pm 0.3^{\mathrm{a}}$ & $13.2 \pm 0.3^{\mathrm{b}}$ & $21.2 \pm 0.4^{\mathrm{c}}$ & $23.8 \pm 1.0^{c}$ & $25.1 \pm 1.1^{c}$ \\
\hline $\mathrm{C}_{20: 4}(n-6)$ & $5.3 \pm 0.4^{\mathrm{a}}$ & $6.1 \pm 0.5^{\mathrm{a}}$ & $8.8 \pm 0.8^{b}$ & $13.7 \pm 1.2^{\mathrm{c}}$ & $26.2 \pm 1.8^{\mathrm{d}}$ \\
\hline $\mathrm{C}_{20: 5}(n-3)$ & $17.3 \pm 0.8^{\mathrm{a}}$ & $11.8 \pm 1.2^{b}$ & $7.1 \pm 0.7^{\mathrm{c}}$ & $3.4 \pm 0.2^{\mathrm{d}}$ & - \\
\hline $\mathrm{C}_{22: 5}(n-3)$ & $4.4 \pm 0.2^{\mathrm{a}}$ & $4.2 \pm 0.3^{\mathrm{a}}$ & $3.6 \pm 0.4^{\mathrm{ab}}$ & $2.5 \pm 0.3^{b}$ & - \\
\hline $\mathrm{C}_{22: 6}(n-3)$ & $12.7 \pm 0.5^{\mathrm{a}}$ & $11.7 \pm 0.7^{\mathrm{ab}}$ & $10.5 \pm 0.3^{b}$ & $6.4 \pm 0.2^{c}$ & $1.1 \pm 0.1^{\mathrm{d}}$ \\
\hline $\mathrm{C}_{20: 5} / \mathrm{C}_{20: 4}$ ratio & $3.30 \pm 0.22^{a}$ & $1.93 \pm 0.11^{\mathrm{b}}$ & $0.87 \pm 0.14^{\mathrm{c}}$ & $0.26 \pm 0.04^{\mathrm{d}}$ & - \\
\hline
\end{tabular}

The percentages of dietary fish oil and corn oil for the groups : (I) $10: 0$, (II) $7.5: 2.5$, (III) $5.0: 5.0$, (IV) $2.5: 7.5$, (V) $0: 10$. Values are means \pm SE. $(n=6)$. Values in a horizontal line not sharing a common superscript letter are significantly different at $p<0.05$.

料を投与した場合の肝臓脂質の結果は Table 2 に示し た。

TC はコーン油の配合比率が増加するにつれて有意に 低下を示し，血墏コレステロールと異なる傾向を示した が, TG では変動が認められなかった。PL では, コー ン油の配合割合の増加により低下傾向を示した。

\section{2. 脂肪酸組成の变動}

1) 血漿脂肪酸組成 血漿脂肪酸組成の結果は Table 3 に示した。飼料脂質の魚油とコーン油の配合比率の変 化にともない変動したおるな脂肪酸は $\mathrm{C}_{16: 0}, \mathrm{C}_{16: 1}$, $\mathrm{C}_{18: 0}, \mathrm{C}_{18: 1}, \mathrm{C}_{18: 2}, \mathrm{C}_{20: 4}, \mathrm{C}_{20: 5}$ および $\mathrm{C}_{22: 6}$ であった。 このうち, $\mathrm{C}_{16: 0}, \mathrm{C}_{16: 1}, \mathrm{C}_{18: 1}, \mathrm{C}_{20: 5}$ および $\mathrm{C}_{22: 6}$ の割 合はいずれす魚油の配合割合が減少するにつれて低下を 示した。 $\mathrm{C}_{18: 2}$ と $\mathrm{C}_{20: 4}$ のそれぞれの割合は, コーン油の
配合割合が高まるにつれて著しい增加を認め, $\mathrm{C}_{18: 0}$ の割 合は, 魚油とコーン油の配合割合を変化させても変動を 認めなかった。

$\mathrm{C}_{20: 5} / \mathrm{C}_{20: 4}$ 比は飼料脂質の魚油の配合割合が低下する につれて減少し, 魚油とコーン油の配合割合が $50: 50$ の場合に 0.87 と 1 に近い值を示した。

2) 血小板の脂肪酸組成 Table 4 に飼料脂質の魚油 とコーン油の配合割合を变えた場合の血小板の脂肪酸組 成の変動を示した。

変動を示したおもな脂肪酸は， $\mathrm{C}_{16: 0}, \mathrm{C}_{18: 1}, \mathrm{C}_{18: 2}$, $\mathrm{C}_{20: 4}$ および $\mathrm{C}_{20: 5}$ であった。 $\mathrm{C}_{16: 0}$ の割台と $\mathrm{C}_{18: 0}$ の割 合は, 魚油の配合割合が $50 \%$ 以上の範囲では変動せず, 魚油 $25 \%$ レベル以下でやや上昇し，一定值を保ってい た。 $\mathrm{C}_{18: 2}$ の割合は, 魚油の配合割合か; $50 \sim 100 \%$ で高 
Table 4. Effects of different combinations of fish oil and corn oil in diets on fatty acid composition of platelet lipids (\%).

\begin{tabular}{|c|c|c|c|c|c|}
\hline \multirow{2}{*}{ Fatty acids } & \multicolumn{5}{|c|}{ Group } \\
\hline & I & II & III & IV & $\mathrm{V}$ \\
\hline $\mathrm{C}_{14: 0}$ & $2.9 \pm 0.4^{\mathrm{abc}}$ & $2.6 \pm 0.3^{\mathrm{a}}$ & $2.4 \pm 0.1^{\mathrm{b}}$ & $2.6 \pm 0.2^{\mathrm{abc}}$ & $2.4 \pm 0.2 \mathrm{c}$ \\
\hline $\mathrm{C}_{16: 0}$ & $23.0 \pm 1.2^{\mathrm{a}}$ & $20.3 \pm 0.7^{\mathrm{a}}$ & $21.1 \pm 1.1^{\mathrm{a}}$ & $25.5 \pm 1.3^{\mathrm{ab}}$ & $25.8 \pm 0.7^{b}$ \\
\hline $\mathrm{C}_{16: 1}$ & $5.4 \pm 0.5$ & $5.9 \pm 0.7$ & $5.2 \pm 0.4$ & $5.1 \pm 0.6$ & $4.1 \pm 0.3$ \\
\hline $\mathrm{C}_{18: 0}$ & $8.2 \pm 0.6^{\mathrm{ab}}$ & $7.7 \pm 0.3^{a b}$ & $7.0 \pm 0.3^{\mathrm{a}}$ & $12.4 \pm 1.3^{\mathrm{ab}}$ & $12.9 \pm 0.6^{b}$ \\
\hline $\mathrm{C}_{18: 1}$ & $36.2 \pm 2.1^{\mathrm{a}}$ & $38.9 \pm 2.6^{\mathrm{a}}$ & $39.8 \pm 2.2^{\mathrm{a}}$ & $32.3 \pm 2.3^{\mathrm{b}}$ & $28.6 \pm 1.8^{b}$ \\
\hline $\mathrm{C}_{18: 2}(n-6)$ & $10.9 \pm 1.1^{\mathrm{a}}$ & $10.1 \pm 0.4^{\mathrm{a}}$ & $10.2 \pm 0.2^{\mathrm{ab}}$ & $5.8 \pm 0.6^{b c}$ & $6.8 \pm 0.4^{\mathrm{c}}$ \\
\hline $\mathrm{C}_{20: 4}(n-6)$ & $2.7 \pm 0.6^{\mathrm{a}}$ & $2.6 \pm 0.4^{\mathrm{ab}}$ & $3.5 \pm 0.6^{a b}$ & $6.4 \pm 0.9^{b}$ & $11.0 \pm 1.2^{c}$ \\
\hline $\mathrm{C}_{20: 5}(n-3)$ & $4.9 \pm 0.8$ & $3.1 \pm 0.4$ & $2.4 \pm 0.5$ & $1.5 \pm 0.4$ & - \\
\hline $\mathrm{C}_{20: 5} / \mathrm{C}_{20: 4} \quad$ ratio & $1.82 \pm 0.10^{\mathrm{a}}$ & $1.21 \pm 0.05^{\mathrm{b}}$ & $0.69 \pm 0.05^{c}$ & $0.24 \pm 0.04^{\mathrm{d}}$ & - \\
\hline
\end{tabular}

The percentages of dietary fish oil and corn oil for the groups : ( I ) $10: 0$, (II) $7.5: 2.5$, (III) $5.0: 5.0$, (IV) $2.5: 7.5$, (V) $0: 10$. Values are means \pm SE. $(n=6)$. Values in a horizontal line not sharing a common superscript letter are significantly different at $p<0.05$.

Table 5. Effects of different combinations of fish oil and corn oil in diets on fatty acid composition of liver lipids $(\%)$.

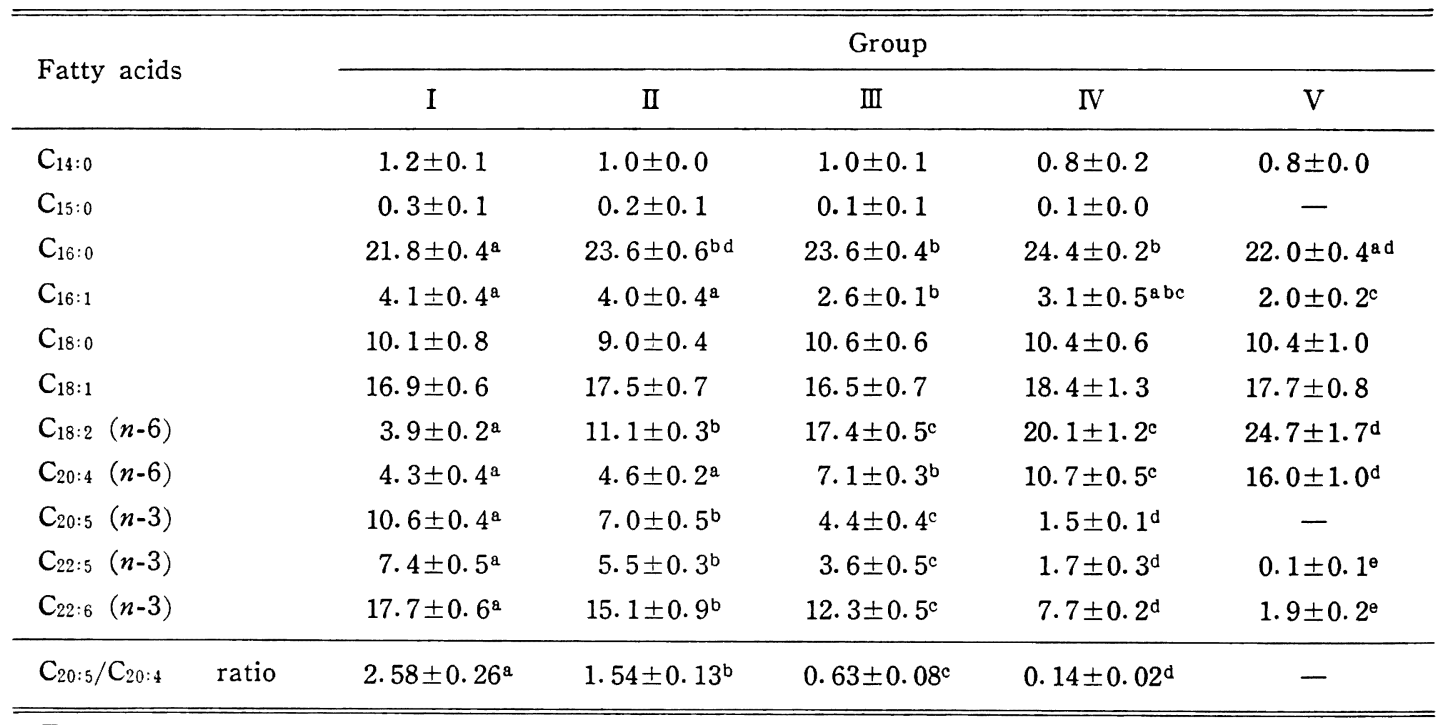

The percentages of dietary fish oil and corn oil for the groups : ( I ) $10: 0$, (II) $7.5: 2.5$, (III) $5.0: 5.0$, (IV) $2.5: 7.5$, (V) $0: 10$. Values are means \pm SE. $(n=6)$. Values in a horizontal line not sharing a common superscript letter are significantly different at $p<0.05$.

く, ほぼ同一の值を示し， $25 \%$ の時に減少したが，魚 油 $0 \%$ でも25\%レベルとほぼ同様な值であった。 $\mathrm{C}_{20: 4}$ の割合は，魚油の配合割合が $50 \sim 100 \%$ の範囲で大きな 変動がみられず，25\% 以下で著しい増加を示した。 $\mathrm{C}_{20: 5}$ の割合は, 魚油の配合割合が減少するにつれて低 下を示した。 $\mathrm{C}_{20: 5} / \mathrm{C}_{20: 4}$ 比は他の組織と同様に, 魚油の 配合割合が減少するにつれて低下し，魚油の配合割合が
$100 \%$ の群で 2 に近い値を示した。

3 ) 肝蔵の脂肪酸組成 魚油とコーン油の配合比率の 変化にともなう, 肝蔵脂肪酸組成の変動はTable 5 に示 した。

肝蔵脂肪酸の中で $\mathrm{C}_{16: 0}$ と $\mathrm{C}_{18: 1}$ の含有割合は比較的 高率であったが, 両脂肪酸の割合は魚油とコーン油の配 合割合を変化させても著明な変動を示さなかった。 $n-6$ 
Table 6. Effects of different combinations of fish oil and corn oil in diets on fatty acid composition of testes lipids (\%).

\begin{tabular}{|c|c|c|c|c|c|c|}
\hline \multirow{2}{*}{\multicolumn{2}{|c|}{ Fatty acids }} & \multicolumn{5}{|c|}{ Group } \\
\hline & & I & II & III & IV & $\mathrm{V}$ \\
\hline $\mathrm{C}_{14: 0}$ & & $1.7 \pm 0.2$ & $0.8 \pm 0.3$ & $0.8 \pm 0.2$ & $0.9 \pm 0.2$ & $1.2 \pm 0.1$ \\
\hline $\mathrm{C}_{16: 0}$ & & $34.1 \pm 0.8$ & $32.9 \pm 1.9$ & $34.1 \pm 0.5$ & $37.0 \pm 3.7$ & $32.4 \pm 0.5$ \\
\hline $\mathrm{C}_{16: 1}$ & & $3.1 \pm 0.4^{\mathrm{a}}$ & $2.5 \pm 0.7^{\mathrm{ab}}$ & $1.7 \pm 0.3^{\mathrm{b}}$ & $1.3 \pm 0.2^{\mathrm{b}}$ & $1.2 \pm 0.1^{\mathrm{b}}$ \\
\hline $\mathrm{C}_{18: 0}$ & & $6.3 \pm 0.2$ & $6.7 \pm 0.3$ & $6.3 \pm 0.2$ & $7.6 \pm 1.0$ & $6.4 \pm 0.2$ \\
\hline $\mathrm{C}_{18: 1}$ & & $17.8 \pm 0.5^{\mathrm{ab}}$ & $17.4 \pm 1.7^{\text {be }}$ & $14.3 \pm 0.6^{c}$ & $11.2 \pm 1.0^{\mathrm{d}}$ & $12.5 \pm 0.5^{\mathrm{d}}$ \\
\hline $\mathrm{C}_{18: 2}(n-6)$ & & $3.1 \pm 0.2^{\mathrm{a}}$ & $6.9 \pm 0.7^{b}$ & $7.8 \pm 0.7^{b}$ & $7.2 \pm 0.9^{b}$ & $8.6 \pm 1.0^{b}$ \\
\hline $\mathrm{C}_{20: 3}(n-6)$ & & $1.0 \pm 0.1$ & $1.2 \pm 0.1$ & $1.2 \pm 0.1$ & $1.1 \pm 0.1$ & $1.0 \pm 0.0$ \\
\hline $\mathrm{C}_{20: 4}(n-6)$ & & $11.1 \pm 0.4^{\mathrm{a}}$ & $11.6 \pm 0.7^{a}$ & $12.6 \pm 0.5^{\mathrm{b}}$ & $13.1 \pm 1.1^{\mathrm{ab}}$ & $14.8 \pm 0.4^{b}$ \\
\hline $\mathrm{C}_{20: 5}(n-3)$ & & $2.0 \pm 0.2^{\mathrm{a}}$ & $1.1 \pm 0.3^{b}$ & $0.3 \pm 0.1^{\mathrm{c}}$ & $0.2 \pm 0.1^{\mathrm{c}}$ & - \\
\hline$C_{22: 4}(n-6)$ & & $1.2 \pm 0.1^{\mathrm{a}}$ & $1.4 \pm 0.1^{\mathrm{ab}}$ & $1.7 \pm 0.1^{\mathrm{bc}}$ & $2.0 \pm 0.2^{\mathrm{c}}$ & $2.7 \pm 0.1^{\mathrm{d}}$ \\
\hline$C_{22: 5}(n-6)$ & & $10.5 \pm 0.4^{\mathrm{a}}$ & $11.8 \pm 1.4^{\mathrm{ab}}$ & $14.9 \pm 0.8^{\mathrm{bc}}$ & $15.1 \pm 1.2^{\mathrm{bc}}$ & $17.0 \pm 0.6^{\mathrm{c}}$ \\
\hline $\mathrm{C}_{22: 5}(n-3)$ & & $0.8 \pm 0.1$ & $0.5 \pm 0.2$ & - & - & - \\
\hline $\mathrm{C}_{22: 6}(n-3)$ & & $6.0 \pm 0.3^{\mathrm{a}}$ & $3.7 \pm 0.3^{b}$ & $3.0 \pm 0.1^{\mathrm{c}}$ & $2.0 \pm 0.2^{\mathrm{d}}$ & $0.9 \pm 0.1^{\mathrm{e}}$ \\
\hline $\mathrm{C}_{20: 5} / \mathrm{C}_{20: 4}$ & ratio & $0.19 \pm 0.03^{\mathrm{a} b}$ & $0.10 \pm 0.03^{b}$ & $0.02 \pm 0.01^{\mathrm{c}}$ & $0.01 \pm 0.01^{\mathrm{c}}$ & - \\
\hline
\end{tabular}

The percentages of dietary fish oil and corn oil for the groups : (I) $10: 0$, (II) $7.5: 2.5$, (III) $5.0: 5.0$, (IV) $2.5: 7.5$, (V) $0: 10$. Values are means \pm SE. $(n=6)$. Values in a horizontal line not sharing a common superscript letter are significantly different at $p<0.05$.

系 PUFA の $\mathrm{C}_{18: 2}$ と $\mathrm{C}_{20: 4}$ の割合は, 飼料脂質のコー ン油の配合割合が高まるにつれて著しく增加することを 認めた。 $n-3$ 系 PUFA の $\mathrm{C}_{20: 5}$ と $\mathrm{C}_{22: 6}$ の割合は, 飼 料脂質の魚油の配合割合が減少するにつれて低下を示し た。

また, $\mathrm{C}_{20: 5} / \mathrm{C}_{20: 4}$ 比も飼料脂質の魚油の配合割合が減 少するにつれて低下を示した。

4 ）睪丸の脂肪酸組成睪丸脂肪酸組成の変動は Table 6 に示した。魚油とコーン油の配合比率の变化に ともなって変動のみられたおもな脂肪酸は $\mathrm{C}_{18: 1}, \mathrm{C}_{18: 2}$, $\mathrm{C}_{20: 4}, \mathrm{C}_{20: 5}, \mathrm{C}_{22: 5}(n-6)$ および $\mathrm{C}_{22: 6}$ であった。 $\mathrm{C}_{18: 2}$ と $\mathrm{C}_{20: 4}$ の割合は, ニーン油の配合割合が増加するにつ れて上昇し， $\mathrm{C}_{18: 1} ， \mathrm{C}_{20: 5}$ および $\mathrm{C}_{22: 6}$ の割合は, 魚油の 配合割合が低下するにつれて減少を示した。しかし，肝 臓と血漿に比較して, 各脂肪酸の变動幅は小さく, また $\mathrm{C}_{20: 5}$ と $\mathrm{C}_{22: 6}$ の取り込みも低く， $\mathrm{C}_{16: 0,} \mathrm{C}_{18: 1}$ および $\mathrm{C}_{22: 5}(n-6)$ の含有割合が著しく高いといら点において 他の組織と異なる脂肪酸パターンを示した。また， $\mathrm{C}_{20: 4}$ は常に $C_{18: 2}$ よりも高值を示し，この点においても他の 組織と異なるパターンが認められた。 $\mathrm{C}_{20: 5} / \mathrm{C}_{20: 4}$ 比は他 の組織と同様, 飼料脂質の魚油の配合割合が低下寸るに つれて減少を示したが, 他の藏器の場合と比べて, 比は 小さかった。

5) 副睪丸周辺脂肪組織の脂肪酸祖成 Table 7 に結
果を示すよらに，飼料中の魚油とコーン油の配合比率の 変化にともなって変動したおもな脂肪酸は $\mathrm{C}_{16: 0}, \mathrm{C}_{16: 1}$, $\mathrm{C}_{18: 2,} \mathrm{C}_{20: 5}$ および $\mathrm{C}_{22: 6}$ であった。

飼料脂質の魚油の配合割合が減少するにつれて, $\mathrm{C}_{16}: 0$, $\mathrm{C}_{16: 1}, \mathrm{C}_{20: 5}$ および $\mathrm{C}_{22: 6}$ の割合は低下することを認めた。 $\mathrm{C}_{18: 2}$ の割合は, コーン油の配合割合が高まるにつれて著 しい増加を示した。 $\mathrm{C}_{18: 0}, \mathrm{C}_{18: 1}$ と $\mathrm{C}_{20: 4}$ の割合は, 飼料 脂質の魚油とコーン油の配合割合が変化するにもかかわ らず，ほとんど変動がみられなかった。全体的に $\mathrm{C}_{16: 0}$ と $\mathrm{C}_{18: 1}$ が高値を、 C $20: 4$ は著しい低値を示した。

また, $C_{18: 3}$ 以上の PUFA が他の組織に比して著しく 少ない点において, 異なる傾向を認めた。

$\mathrm{C}_{20: 5} / \mathrm{C}_{20: 4}$ 比は他の組織と同様, 魚油の配合割合が減 少するにつれて低下を示した。 $\mathrm{C}_{20: 5} / \mathrm{C}_{20: 4}$ 比は $\mathrm{C}_{20: 4}$ の 割合が少ないため，他の組織より高値を示した。

\section{3. 魚油とコーン油の配合割合と $\mathrm{C}_{20: 4} / \mathrm{C}_{18: 2}$ 比の関} 連性

飼料脂質の魚油とコーン油の配台割合を変化させた場 合の各組織の $\mathrm{C}_{20: 4} / \mathrm{C}_{18: 2}$ 比の変動を Fig.1 に示した。

血漿と肝臓においてては魚油の配合割合が 50 および 75 $\%$ の場合, $\mathrm{C}_{20: 4} / \mathrm{C}_{18: 2}$ 比は最小値を示し, 魚油の配合割 合が $75 \%$ を越えても，50\% 未満でも上昇するという， 類似のパターンを示した。

血小板に执いては, 魚油の配合割合が $50 \%$ 以上の場 
Table 7. Effects of different combinations of fish oil and corn oil in diets on fatty acid composition of epididymal lipids (\%).

\begin{tabular}{|c|c|c|c|c|c|}
\hline \multirow{2}{*}{ Fatty acids } & \multicolumn{5}{|c|}{ Group } \\
\hline & I & II & III & IV & $\mathrm{V}$ \\
\hline $\mathrm{C}_{14: 0}$ & $4.0 \pm 0.2^{\mathrm{a}}$ & $3.1 \pm 0.0^{\mathrm{b}}$ & $2.6 \pm 0.1^{\mathrm{c}}$ & $1.8 \pm 0.0^{\mathrm{d}}$ & $1.2 \pm 0.0^{\ominus}$ \\
\hline$C_{16: 0}$ & $28.2 \pm 0.8^{\mathrm{a}}$ & $27.8 \pm 0.8^{\mathrm{a}}$ & $25.5 \pm 0.6^{\mathrm{b}}$ & $21.8 \pm 0.4^{\mathrm{c}}$ & $21.5 \pm 0.9^{d}$ \\
\hline$C_{16: 1}$ & $10.9 \pm 0.4^{\mathrm{a}}$ & $9.7 \pm 0.3^{b}$ & $8.4 \pm 0.2^{c}$ & $6.5 \pm 0.1^{\mathrm{d}}$ & $5.1 \pm 0.2^{\ominus}$ \\
\hline $\mathrm{C}_{18: 0}$ & $3.1 \pm 0.1^{\mathrm{a}}$ & $3.3 \pm 0.1^{\mathrm{a}}$ & $2.9 \pm 0.1^{\mathrm{a}}$ & $2.4 \pm 0.1^{\mathrm{b}}$ & $2.5 \pm 0.1^{b}$ \\
\hline $\mathrm{C}_{18: 1}$ & $28.2 \pm 0.6$ & $28.7 \pm 0.4$ & $29.8 \pm 0.4$ & $29.2 \pm 0.2$ & $28.8 \pm 0.5$ \\
\hline $\mathrm{C}_{18: 2}(n-6)$ & $6.8 \pm 1.5^{\mathrm{a}}$ & $14.1 \pm 0.5^{b}$ & $24.3 \pm 0.6^{c}$ & $33.2 \pm 0.5^{\mathrm{d}}$ & $39.4 \pm 1.2^{\ominus}$ \\
\hline $\mathrm{C}_{18: 3}(n-3)$ & $1.0 \pm 0.1^{\mathrm{a}}$ & $0.7 \pm 0.0^{\mathrm{b}}$ & $0.5 \pm 0.0^{\mathrm{c}}$ & $0.5 \pm 0.1^{\mathrm{c}}$ & $0.5 \pm 0.1^{\mathrm{c}}$ \\
\hline $\mathrm{C}_{20: 1}$ & $4.0 \pm 0.3^{a}$ & $3.0 \pm 0.2^{\mathrm{b}}$ & - & - & - \\
\hline $\mathrm{C}_{20: 4}(n-6)$ & $0.4 \pm 0.1$ & $0.4 \pm 0.0$ & $0.4 \pm 0.1$ & $0.5 \pm 0.0$ & $0.5 \pm 0.1$ \\
\hline $\mathrm{C}_{20: 5}(n-3)$ & $3.9 \pm 0.4^{a}$ & $2.9 \pm 0.1^{b}$ & $1.6 \pm 0.2^{c}$ & $0.8 \pm 0.0^{\mathrm{d}}$ & - \\
\hline $\mathrm{C}_{22: 5}(n-3)$ & $1.2 \pm 0.3^{\mathrm{ac}}$ & $1.1 \pm 0.1^{\mathrm{c}}$ & $0.7 \pm 0.2^{\mathrm{ab}}$ & $0.6 \pm 0.0^{\mathrm{b}}$ & - \\
\hline $\mathrm{C}_{22: 6}(n-3)$ & $4.2 \pm 0.5^{\mathrm{a}}$ & $3.5 \pm 0.1^{\mathrm{a}}$ & $1.8 \pm 0.3^{b}$ & $1.1 \pm 0.0^{\mathrm{b}}$ & - \\
\hline $\mathrm{C}_{20: 5} / \mathrm{C}_{20: 4} \quad$ ratio & $8.09 \pm 1.91^{\mathrm{ab}}$ & $8.02 \pm 0.43^{b}$ & $5.09 \pm 0.76^{\mathrm{a}}$ & $1.55 \pm 0.11^{\mathrm{c}}$ & - \\
\hline
\end{tabular}

The percentages of dietary fish oil and corn oil for the groups : (I ) $10: 0$, (II) $7.5: 2.5$, (III) $5.0: 5.0$, (IV) $2.5: 7.5$, (V) $0: 10$. Values are means \pm SE. $(n=6)$. Values in a horizontal line not sharing a common superscript letter are significantly different at $p<0.05$.

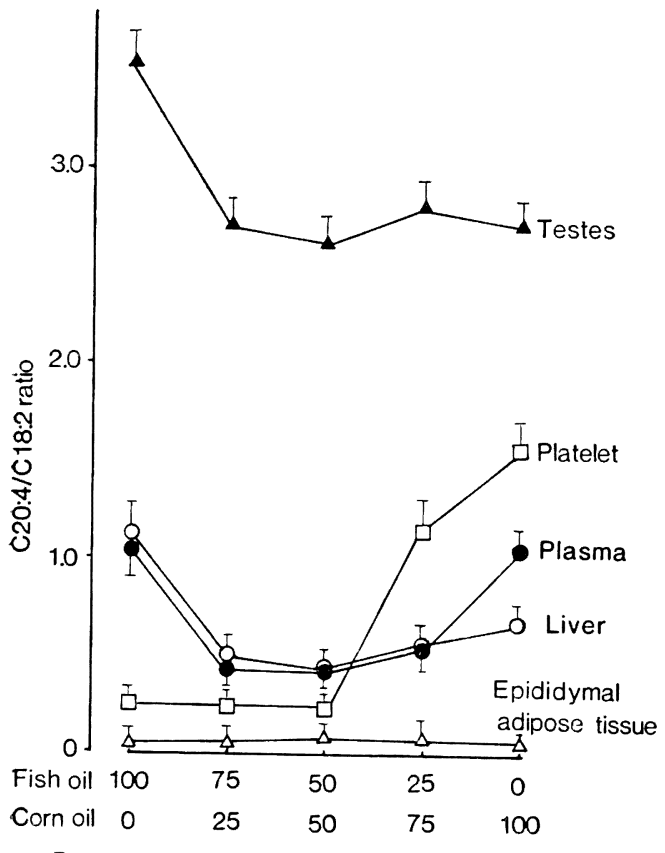

Proportion of fish and corn oils in diet (\%)

Fig.1. Effects of different combinations of fish oil and corn oil in diets on $\mathrm{C}_{20: 4} / \mathrm{C}_{18: 2}$ ratios of tissue lipids.

Data represent means $\pm \mathrm{SE}$. of six rats.
合, $\mathrm{C}_{20: 4} / \mathrm{C}_{18: 2}$ 比は低い值を示し, 魚油の配合割合が 50 \%未満のときに $\mathrm{C}_{20: 4} / \mathrm{C}_{18: 2}$ 比は直線的に増加し, 他の組 織と異なる傾向を示した。

睪丸の $\mathrm{C}_{20: 4} / \mathrm{C}_{18: 2}$ 比は, 魚油の配合割合が $100 \%$ か ら $75 \%$ に低下する段階で著しく減少し，75\% 以下では ほぼ一定であった。

副睪丸周辺脂肪組織においては, 魚油とニーン油の配 合割合が変化するにもかかわらず $\mathrm{C}_{20: 4} / \mathrm{C}_{18: 2}$ 比はいずれ も低く，変動が認められなかった。

$$
\text { 考察 }
$$

$n-3$ 系 PUFA が $n$-6 系 PUFA と同様生体内で重要 な機能を有することが判明して以来7) 10)13) 15)，食事中 の $n-3 \mathrm{P} / n-6 \mathrm{P}$ 比は $\mathrm{P} / \mathrm{S}$ 比と同様に重要視されるように なった。

今回の実験において飼料脂質は魚油の割合が低下する につれて $n-3 \mathrm{P} / n-6 \mathrm{P}$ 比が減少する。また, 魚油の割合が 低下することはコーン油の割合が高まり, P/S 比が上昇 するように調製されている。このような奉験系において 血漿 TG は有意な変動が認められず, Mouri ら11の魚 油の配合割合が高まれば，血清TGが有意に低下すると いう報告とは異なる結果を得た。

一般的に, $n-3$ 系 PUFA と $n-6$ 系PUFA の両方に 血漿 TC 低下作用が認められているが，低下作用は $n-3$ 系 PUFA の涪うが強いとの報告が多(6)16)17)。先に 
Mouri ら11 は，魚油の配合割合が高まるにつれて，TC が有意に低下することを報告している。著者らも今回同 様な結果を得, 血漿 $\mathrm{TC}$ は $n-3 \mathrm{P} / n-6 \mathrm{P}$ 比の增加につれ て減少することを認めた。血墏 TC の低下を目的とする のであれば飼料中の $n-3 \mathrm{P} / n-6 \mathrm{P}$ 比を高めることも優れ た一手法であることが示唆された。

血中 HDL-Chol は Miller $5^{18) \sim 21) ~}$ が HDL-Chol の 低い人は虚血性心疾患をおこしやすいと報告して以来, HDL-Chol の抗動脈硬化作用が注目を集めている。本実 験に沶いて血漿 HDL-Chol は $n-3 \mathrm{P} / n-6 \mathrm{P}$ 比の最も小さ いコーン油 $100 \%$ 投与群で有意に高值を示し， $n-3$ 系 PUFA より $n-6$ 系 PUFA のほうが血漿 HDL-Chol の 上昇作用が強いものと推測された。

血漿之肝臓の脂肪酸組成は, 魚油の配合割合が減少す れば $\mathrm{C}_{20: 5}$ と $\mathrm{C}_{22: 6}$ のそれぞれの割合は低下, コーン油 の配合割合が高まれば $\mathrm{C}_{18: 2}$ と $\mathrm{C}_{20: 4}$ は上昇，といった 類似のパターンを認め, 飼料脂質の直接的な影響を受け ることが明らかとなった。

血小板においては，魚油の配合割合が $50 \%$ 以上の場 合 $\mathrm{C}_{18: 2}$ の割合が高く、 $\mathrm{C}_{20: 4}$ の割合は低かった。しか し, 魚油の割合が $50 \%$ 未満になりコーン油の割合が 50 $\%$ 以上增加した場合， $\mathrm{C}_{18: 2}$ の割合は逆に低下し， $\mathrm{C}_{20: 4}$ の割合は增加した。なお，コーン油 $50 \%$ 以上の場 合, 血小板の $\mathrm{C}_{18: 2}$ の割合が低かったのは血漿から血小 板への $\mathrm{C}_{18: 2}$ の取り込みの減少，西るいは血小板におけ る $\mathrm{C}_{18: 2}$ から $\mathrm{C}_{20: 4}$ への転換の促進のいずれか，または この二つの原因が重なったためと思われる。

睪丸においては, $n$-3 系 PUFA の $\mathrm{C}_{20: 5}$ と $\mathrm{C}_{22: 6}$ の 取り込みが少なく, これに反して $\mathrm{C}_{20: 4}$ が比較的多く, また, ニーン油の配合割合の高低にあまり影響を受けず ほぽ一定の値を示し, 他の組織に比して $n$ - 6 系 PUFA の $\mathrm{C}_{22: 5}$ が著しく高値を示したことから, 睪丸では $n-3$ 系 PUFA より $n-6$ 系 PUFA のほうが生殖機能維持に 重要な働きをしているものと考兄られる。この点関し て今後, 詳細に検討寸べきであると考光ている。

副睪丸周边脂肪組織においては，コーン油の配合割合 が高まるにつれて $\mathrm{C}_{18: 2}$ は著しく增加し, 一方では $\mathrm{C}_{20: 4}$ は 0.4 0.5\% と低值を示し, $\mathrm{C}_{18: 2}$ から $\mathrm{C}_{20: 4}$ への転換 が,なんらかの機構が働いて著しく抑制されているもの と考えられる。これらの点を考光合わせると, 副㐿丸周 辺脂肪組織は土ネルギー蓄積能とともに, $\mathrm{C}_{15: 2}$ の蓄稓能 も備えているように考えられた。

$\mathrm{C}_{20: 4} / \mathrm{C}_{18: 2}$ 比は組織によって異なり, また，魚油とコ ーン油のそれぞれの配合割合によっても異なることが認 められた。これは,リノール酸の代謝が組織のみなら ず, 魚油とコーン油の配合割合, すなわち, $n-3 \mathrm{P} / n-6 \mathrm{P}$ 比によっても異なることを示すものである。とくに血小
板においては，魚油とコーン油の割合がそれぞれ $50 \%$ ， すなわち $n-3 \mathrm{P} / n-6 \mathrm{P}$ 比 0.5 を境にして, それ以上では $\mathrm{C}_{18: 2}$ から $\mathrm{C}_{20: 4}$ への転換が著しく抑制され，同 0.5 以下 では $\mathrm{C}_{18: 2}$ から $\mathrm{C}_{20: 4}$ への転換が促進されると考えられ る。このことは, Fig.1 からもらかがえる。さらに睪丸 においては, すべての群において肝蔵, 血漿より $\mathrm{C}_{20: 4} /$ $\mathrm{C}_{18: 2}$ 比が著しく高く, $\mathrm{C}_{18: 2}$ から $\mathrm{C}_{20: 4}$ への転換の高い ことを示するのであろう。このことは殬丸における AA の必要性が血漿および肝蔵とは異なるためではないかと 推測された。なお, 血墏, 肝臓, 颪丸の魚油 $100 \%$ 群に おいて $\mathrm{C}_{20: 4} / \mathrm{C}_{18: 2}$ 比の高値がみられたのは, 摂取 $\mathrm{C}_{18: 2}$ に比し, 組織中に残存する $\mathrm{C}_{20: 4}$ の量が多かったためで はないかと考えられた。

$$
\text { 要約 }
$$

魚油とコーン油の配合割合の異なる飼料をラットに投 与した場合の血墏, 血小板, 肝蔵, 睪丸および副辠丸周 辺脂肪組織の脂質代謝变動を中心に検討し, 次の結果を 得た。

1）血漿 TC は魚油の配合割合が上昇するにつれて低 下を示した。一方, 血漿 TG と PL は, 魚油とコーン 油の割合が異なっても各群間に有意差を認めなかった。

2) 肝臓の TC と PL は, コーン油の配合割合が増 加すると低下することが認められた。TGレペルは魚油 とコーン油の配合割合が異なるにもかかわらず各群間で 有意な差は認められなかった。

3) 血漿と肝臓の脂肪酸組成は, 魚油の配合割合が減 少するにつれて $\mathrm{C}_{20: 5}$ と $\mathrm{C}_{22: 6}$ は低下し, コーン油の割 合が高まるにつれて $\mathrm{C}_{18: 2}$ と $\mathrm{C}_{20: 4}$ は上昇を示した。血 小板では魚油の配合割合が $50 \sim 100 \%$ で $\mathrm{C}_{18: 2}$ の割合は 高く, $\mathrm{C}_{20: 4}$ の割合は低かった。 $50 \%$ 未満では $\mathrm{C}_{18: 2}$ は 減少， $\mathrm{C}_{20: 4}$ は上昇を示した。殬丸では $n-6$ 系 PUFA の $\mathrm{C}_{20: 4}$ と $\mathrm{C}_{22: 5}$ が他の組織に比して高値を示した。脂 肋組織では, コーン油の配合割合が高まるにつれて $\mathrm{C}_{18: 2}$ が著しく上昇した。各組織の $\mathrm{C}_{20: 5} / \mathrm{C}_{20: 4}$ 比は飼料脂質の 魚油の配合割合が減少するにつれて低下を示した。

4) $\mathrm{C}_{20: 4} / \mathrm{C}_{18: 2}$ 比は組織によって異なり，また，魚油 とコーン油のそれぞれの配合割合によっても異なること が認められた。

\section{文献}

1) Dyerberg, J., Bang, H.O. and Hjprne, N.: Am. J. Clin. Nutr., 28, 958 (1975)

2) Bang, H.O. and Dyerberg, J. : Adv. Nutr. Res., 3, 1 (1980)

3) Dyerberg, J. and Bang, H.O. : Lancet, 1, 433 (1979)

4) Nagakawa, Y., Orino, H., Harasawa, M., Yashiro, K. and Murota, S. : Atherosclerosis, 47, 71 (1983) 
5) Sen, D.P.:J. Am. Oil Chem. Soc., 54, 297 (1977)

6) Lossonczy, T.O., Ruiter, A., BronsgestSchoute, H.C., Gent, C.M. and Hermus, R.J. J. : Am. J. Clin. Nutr., 31, 1340 (1978)

7) Siess, W., Ross, P., Scherer, B., Kurzman, I., Bohling, B. and Weber, P.C. : Lancet, 1, 441 (1980)

8) Spector, A.A., Kaduce, T.L., Figard, P.H. Norton, K.C., Hoak, J.C. and Czervionke, R.L. : J. Lipid Res., 24, 1595 (1983)

9) Needleman, P., Raz, A., Minkes, M.S., Ferrendelli, J.A. and Sprecher, H. : Proc. Natl. Acad. Sci. USA, 76, 944 (1979)

10) Needleman, P., Whitaker, M.O., Wyche, A., Watters, K., Sprecher, H. and Raz, A. : Prostaglandins, 19, 165 (1980)

11) Mouri, K., Ikesu, H., Esaka, T. and Igarashi, O. : J. Nutr. Sci. Vitaminol., 30, 307 (1984)

12) Lee, J.H., Sugano, M. and Ide, T. : J. Nutr. Sci. Vitaminol., 34, 117 (1988)

13) Dyerberg, J., Bang, H.O., Stoffersen, E.,
Moncada, S. and Vane, J.R. : Lancet, 15, 117 (1978)

14) Fischer, S. and Weber, P.C. : Biochem. Biophys. Res. Commun., 116, 1091 (1983)

15) Fischer, S. and Weber, P.C. : Nature, 307, 165 (1984)

16) Goodnight, S.H., Harris, W.S., Connor, W.E. and Illingworth, D.R. : Arteriosclerosis, 2, 87 (1982)

17) Connor, W.E., Lin, D.S. and Harris, W.B.: Arteriosclerosis, 1, 363 a (1981)

18) Miller, G.J. and Miller, N.E. : Lancet, 1, 16 (1975)

19) Rhoads, G.G., Gulbrandsen, C.L. and Kagan, A. : N. Engl. J. Med., 294, 293 (1976)

20) 山本 章, 石川勝憲, 松沢佑次, 三杉 進, 首藤 弘史：動脈硬化，3，261 (1975)

21) Gordon, T., Castelli, W.P., Hjortland, M.C., Kannel, W.B. and Dawber, T.R.: Am. J. Med., 62, 707 (1977)

(1988 年 6 月 17 日受理) 